\title{
A new bryozoan genus from the Jurassic of Switzerland, with a review of the cribrate colony-form in bryozoans
}

\author{
Paul D. Taylor
}

Received: 6 September 2011 / Accepted: 25 October 2011/Published online: 8 November 2011

(C) Crown Copyright 2011

\begin{abstract}
Very few Jurassic bryozoans have been recorded from Switzerland. The discovery in the collections of the Universität Zurich of a very distinctive cyclostome bryozoan from the Aalenian of Gelterkinden in the BaselCountry Canton, warrants the creation of a new monospecific genus, Rorypora gen nov. The type species of Rorypora, Diastopora retiformis Haime, 1854, was originally described from the French Bajocian. This genus has a 'cribrate' colony-form comprising flattened bifoliate fronds that bifurcate and coalesce regularly to enclose ovoidal lacunae. Unlike the much commoner fenestrate colonyform, apertures of feeding zooids open on both sides of the fronds. The taxonomic distribution of cribrate colonies in bryozoans is reviewed. They are most common in Palaeozoic ptilodictyine cryptostomes but are also found among Palaeozoic cystoporates and Cenozoic cheilostomes, as well as the single known cyclostome example described here. Cribrate colonies therefore provide a striking example of multiple evolutionary convergence. In contrast to fenestrate colony-forms, feeding currents cannot be channelled through the lacunae in cribrate colonies to generate a one-way flow of water for efficient suspension feeding. Instead, the holes are inferred to be the locations of chimneys over which exhalent currents are vented in opposite directions on either side of the planar colony.
\end{abstract}

Electronic supplementary material The online version of this article (doi:10.1007/s13358-011-0027-2) contains supplementary material, which is available to authorized users.

P. D. Taylor $(\square)$

Department of Palaeontology, Natural History Museum,

Cromwell Road, London SW7 5BD, UK

e-mail: P.Taylor@nhm.ac.uk
Keywords Cyclostomata - Convergent evolution . Functional morphology $\cdot$ Feeding

\section{Introduction}

The Jurassic was an unusual period for bryozoans, characterized by a low diversity biota of about 175 species which are most abundant in the Middle Jurassic, have a patchy geographical distribution, and are dominated by species of the order Cyclostomata (Taylor and Ernst 2008). Rarefaction analysis of data on the rate of description of new species over the past 200 years (Taylor and Ernst 2008; Fig. 1) predicts, however, that many more species of Jurassic bryozoans remain to be discovered and described. The Swiss Jurassic has yielded very few bryozoans: de Tribolet described two encrusting cyclostome species: Berenicea foliacea de Tribolet, 1872, and B. sparsicellula de Tribolet, 1873. Walter (1970, p. 121) revised the first of these species, from the Oxfordian, assigning it to Plagioecia. The identity of $B$. sparsicellula remains unclear (Walter 1970, p. 220).

An unexpected find in the bryozoan collections of the Paläontologisches Institut der Universität Zurich during a recent visit was a highly distinctive Jurassic cyclostome that forms the subject of the current paper. Unlike the two species described by de Tribolet $(1872,1873)$, this species has an erect colony-form belonging to a relatively uncommon morphology known as 'cribrate'. The single specimen was collected from the Aalenian MurchisonaeSchichten of Rickenbacher Flue, Gelterkinden in the BaselCountry. It can be identified as a species that was originally described as Diastopora retiformis Haime, 1854 from 'l'oolite inférieure' of Lorraine, France (Lower Bajocian according to Walter 1970). 
Fig. 1 Jurassic cyclostome Rorypora retiformis (Haime, 1854) showing the cribrate colony-form. PIMUZ 6791; Late Aalenian, Dogger, Murchisonae-Schichten; Rickenbacher Flue, Gelterkinden, Kanton Baselland, Switzerland



Cribrate bryozoan colonies have planar colonies of flattened fronds that divide and anastomose to enclose oval holes (lacunae). Superficially they resemble a much commoner bryozoan colony-form called 'fenestrate'. Functionally, however, a critical difference is that cribrate colonies have feeding zooids opening on both sides of the flattened branches whereas they open only on one side in fenestrate colonies. This has major implications for the feeding current patterns established by living colonies, as discussed below. The widely dispersed taxonomic distribution of cribrate colonies within the Bryozoa is reviewed. As previously noted by Schmidt and Bone (2004), the cribrate colony-form provides an excellent example of evolutionary convergence.

\section{Materials and methods}

This study is based on museum collections held by the Paläontologisches Institut und Museum, Universität Zurich, Switzerland (PIMUZ) and the Natural History Museum, London, UK (abbreviated NHML).

Material was studied at the NHM using optical microscopes and a low vacuum scanning electron microscope (LEO VP-1455) which imaged uncoated specimens using back-scattered electrons. Zooidal measurements were made from SEM micrographs. In order to determine the area of the lacunae in cribrate colonies, images of NHM specimens taken using a digital camera were read into the program ImageJ, the lacunae were outlined and their areas computed. In cases where the NHM collections did not contain any material, a similar procedure was followed but using images acquired by flatbed scanning of published illustrations.

\section{Systematic palaeontology}

Cyclostomata Busk, 1852

Tubuliporina Milne Edwards, 1838.

Multisparsidae Bassler, 1935.

Rorypora gen. nov.

\section{Type species Diastopora retiformis Haime, 1854.}

Diagnosis Colony erect, cribrate, comprising strap-like bifoliate branches dividing and anastomosing regularly to give a planar colony containing elongate ovoidal lacunae; early astogeny unknown; skeletal organization fixed-walled, zooids budding from median lamina, opening on both sides. Autozooids with calcified frontal walls, relatively flat; apertures subcircular. Kenozooids closed by calcified 
frontal walls developed around lacunae. Gonozooids unknown.

Etymology Named for Rory Milne (1940-2011), late friend and greatly valued volunteer in the fossil bryozoan group at the NHM.

Remarks The cribrate colony-form of Rorypora, with a reticulate colony comprising strap-like branches with autozooids opening on both sides, distinguishes the genus from all other cyclostome bryozoans. The fixed-walled, non-articulated morphology places the new genus in the suborder Tubuliporina. As currently conceived, Tubuliporina is polyphyletic or paraphyletic (Waeschenbach et al. 2009). Tubuliporine families are diagnosed using gonozooid characters. The two families in which Rorypora potentially could be placed are Multisparsidae Bassler, 1935 and Plagioeciidae Canu, 1918. Unfortunately, gonozooids have not been found in Rorypora but two features strongly suggest that it belongs to Multisparsidae. The first feature is the flat autozooidal frontal walls, characteristic of many (although not all) Jurassic multisparsids but not of plagioeciids in which autozooidal frontal walls are invariably convex. Secondly, autozooidal boundary walls are raised in Rorypora, as seen in the type species of Multisparsa (e.g. Taylor 2009; Fig. 4d-f).

Walter (1970) regarded Diastopora retiformis Haime, 1854 , the type species of Rorypora, as a junior synonym of Mesenteripora davidsoni (Haime, 1854). However, M. davidsoni, originally described from the Bathonian of the type area in Avon, England, possesses foliaceous colonies with broad fronds ('eschariform') which are folded and lack lacunae. In contrast, the cribrate colonies of Rorypora are constructed of narrow, strap-like branches ('adeoniform') dividing and anastomosing in a regular pattern. Although cyclostome bryozoans can exhibit substantial ecophenotypic variation in colony-form (e.g. Harmelin 1976), it is considered unlikely that such a major transition is possible in a single species and the supposed synonymy with $M$. davidsoni is not supported.

Distribution Aalenian-Bajocian, France and Switzerland.

Rorypora retiformis (Haime, 1854)

Figs. 1, 2

1854 Diastopora retiformis Haime, 191, pl. 7, Fig. 9a-b. 1970 Mesenteripora davidsoni Walter, 105 (part), pl. 10, Fig. 2 only.

Type The whereabouts of Haime's type material of Diastopora retiformis is unknown and may be lost, as with the other species he described from the Terquem Collection
(Walter 1970). Topotypical material is currently unavailable but, as the identity of the species is not in doubt (Haime's figures are very clear), a neotype is not chosen here.

Referred material PIMUZ 6791. Jurassic, Late Aalenian, Dogger, Murchisonae-Schichten; Rickenbacher Flue, Gelterkinden, Kanton Baselland, Switzerland; collected by Dr Hans Holenweg (Pratteln), donated to the MUZ, 22 November 1991. A fractured colony in limestone matrix (Fig. 1).

Description Colony erect, cribrate, with narrow, straplike branches about $1.5-5 \mathrm{~mm}$ wide and about $0.9 \mathrm{~mm}$ deep, elongate ovoidal in cross section; branches bifoliate with median budding lamina; regular division and anastomosis of branches occurring in a single plane, giving a foliaceous colony containing ovoidal lacunae which are elongated parallel to growth direction and measure $1.0-2.1 \mathrm{~mm}$ (average $1.6 \mathrm{~mm}$ ) long by $0.8-1.8 \mathrm{~mm}$ (average $1.3 \mathrm{~mm}$ ) wide (Fig. 2a, b). Early astogeny unknown. Fractured interzooidal walls reveal transversely fibrous ultrastructural fabric (Fig. 2f).

Autozooids fixed-walled; frontal walls relatively flat (Fig. 2c, d), 0.52-0.78 $\mathrm{mm}$ (average $0.66 \mathrm{~mm}$ ) long, $0.15-0.18 \mathrm{~mm}$ (average $0.16 \mathrm{~mm}$ ) wide; boundary walls salient (Fig. 2e). Apertures subcircular to slightly elongate longitudinally, $0.09-0.12 \mathrm{~mm}$ (average $0.11 \mathrm{~mm}$ ) in diameter, subterminal, a small area of frontal wall usually present distal of the aperture; peristomes lacking apart from a slightly raised apertural rim; terminal diaphragms apparently closing many apertures (Fig. 2e). Pseudopores circular, about $10 \mu \mathrm{m}$ in diameter.

Kenozooids developed around lacunae (Fig. 2b) and at branch anastomoses, lacking apertures, typically longer and narrower than autozooids, frontal walls complete. Gonozooids unknown.

Remarks This species is unique among Jurassic bryozoans in having a cribrate colony-form. Indeed, it appears to be the only cyclostome from any part of the stratigraphical column with this colony morphology. Haime (1854) originally assigned $M$. retiformis to Diastopora Lamouroux, 1821 , but this was at a time when the concept of Diastopora was very liberal. In accordance with the characters of the Jurassic type species D. foliacea Lamouroux, 1821, Diastopora is nowadays applied to plagioeciid cyclostomes with unifoliate fronds, typically in the form of tubes of wide diameter (see Walter 1970). This morphology is unlike the bifoliate, cribrate colony-form of $M$. retiformis. The species clearly differs from Mesenteripora davidsoni (Haime, 1854), which Walter (1970) regarded as a senior synonym, most obviously in having a cribrate colony-form. 

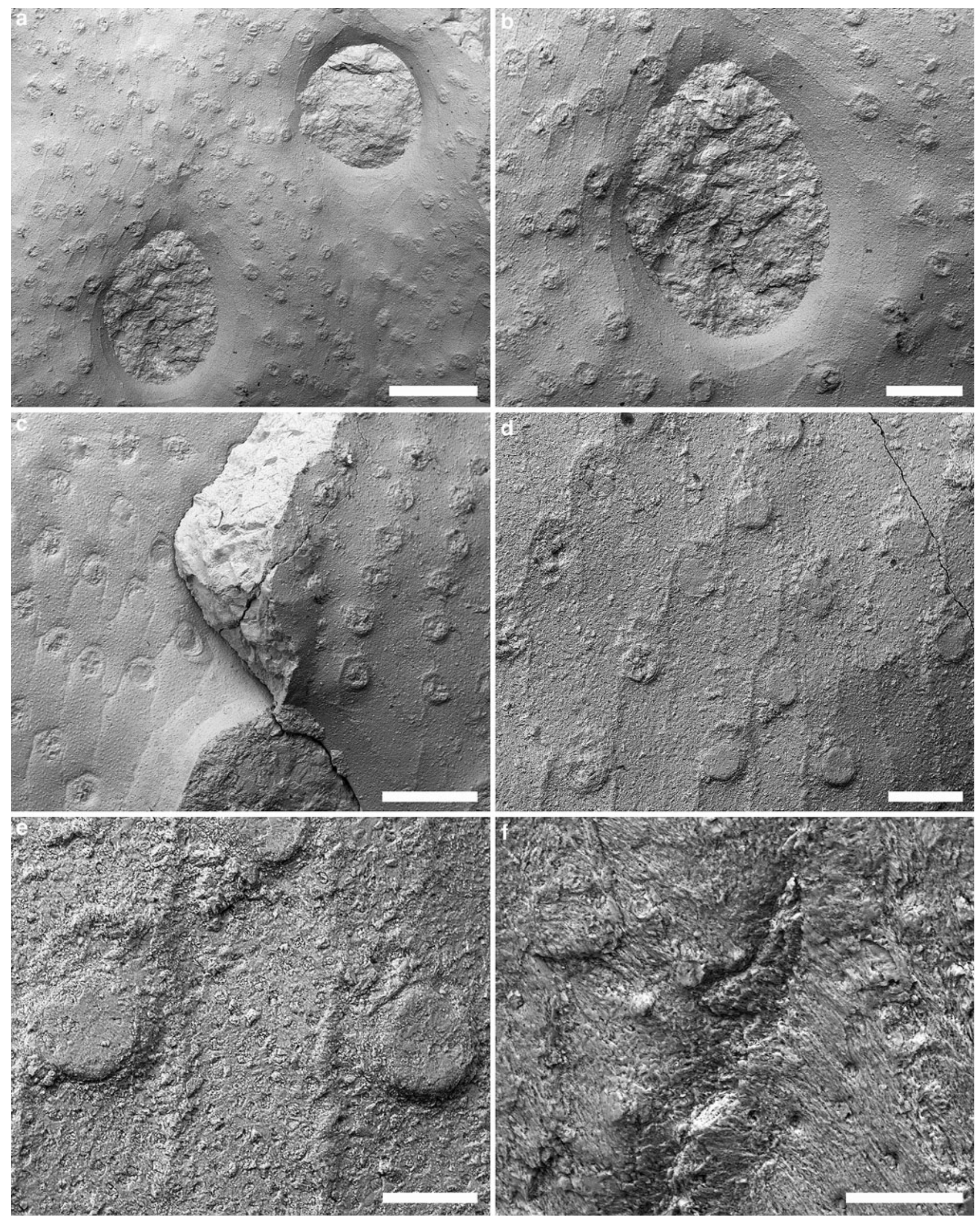
4 Fig. 2 Scanning electron micrographs of Rorypora retiformis (Haime, 1854); Jurassic, Late Aalenian, Dogger, MurchisonaeSchichten; Rickenbacher Flue, Gelterkinden, Kanton Baselland, Switzerland. a Branches and two sediment-filled lacunae. b Lacuna surrounded by kenozooids. c Branch partly broken away to reveal moulds of zooids opening on opposite side of branch. d Autozooids. e Salient zooidal boundary walls and two autozooidal apertures apparently closed by terminal diaphragms. f Fractured interzooidal wall with pores and transversely fibrous skeletal fabric. Scale bars a $1 \mathrm{~mm}, \mathbf{b}, \mathbf{c} 500 \mu \mathrm{m}, \mathbf{d} 200 \mu \mathrm{m}$, e $100 \mu \mathrm{m}$, f $50 \mu \mathrm{m}$

Distribution of cribrate colonies

Despite being among the least common of bryozoan colony-forms, cribrate colonies are widely distributed across the phylum (Table 1). They can be found in four of the six or seven bryozoan orders with calcified skeletons: Cystoporata, Cryptostomata, Cyclostomata and Cheilostomata. The absence of cribrate colonies in Fenestrata is explained by the fact that a key apomorphy of this order is the confinement of feeding zooids to one side of the erect colony branches, whereas cribrate colonies by definition have feeding zooids on both sides of the branches. Another dominant Palaeozoic-Triassic order with no known cribrates, the Trepostomata, seldom develops bifoliate colonies with flattened branches, which are a prerequisite for evolution of the cribrate colony-form (see below). Finally, the Timanodictyida, a low diversity, putative order of Devonian-Permian stenolaemates, appears not to include any cribrate representatives despite often possessing bifoliate colonies (Goryunova 1994).

Cryptostomes of the suborder Ptilodictyina contain the greatest number of cribrate genera, nine distributed between three or five families depending on whether the classification of Goryunova and Lavrentjeva (1993) or Karklins (1983) is followed. In contrast, cribrate colonies are found in only three genera of cystoporates, one cyclostome genus and four cheilostome genera. Given that cheilostomes are by far the most genus-rich bryozoan order, the small number of cribrate genera is particularly striking. Most cheilostome species with cribrate colonies belong to the genus Adeona in which the majority of the approximately 15 species have cribrate colonies, including the type species A. grisea Lamouroux, 1812 (see Kirchenpauer 1880). Ironically, Adeona lends its name to the adeoniform bryozoan growth-form (e.g. Schopf 1969), used for cheilostomes with narrow, strap-like branches but without the planar form and regular cross connections of cribrate colonies. Unusually among cribrate bryozoans, colonies of Adeona are anchored in unconsolidated substrates using their rhizoids; other cribrates cement to hard substrates or grow over semiconsolidated sediment (Spjeldnaes 1996).

Table 1 Bryozoan taxa with cribrate colonies

\begin{tabular}{|c|c|c|c|c|}
\hline Order & Family & Genus/species & Age & References \\
\hline \multirow[t]{3}{*}{ Cystoporata } & Hexagonellidae & Coscinium & Permian & Utgaard (1983) \\
\hline & Hexagonellidae & Coscinotrypa & Devonian & Utgaard (1983) \\
\hline & Etherellidae & Etherella & Permian & Utgaard (1983) \\
\hline \multirow[t]{9}{*}{ Cryptostomata } & Ptilodictyidae & Phaenoporella & Ordovician-Silurian & Karklins (1983) \\
\hline & Ptilodictyidae & Clathropora & Ordovician-Devonian & Karklins (1983) \\
\hline & Ptilodictyidae & Oanduellina & Ordovician & $\begin{array}{l}\text { Goryunova and Lavrentjeva } \\
\text { (1993) }\end{array}$ \\
\hline & Ptilodictyidae & Prophyllodictya & Ordovician & $\begin{array}{l}\text { Goryunova and Lavrentjeva } \\
\text { (1993) }\end{array}$ \\
\hline & Stictoporellidae & Stictoporellina & Ordovician & Karklins (1983) \\
\hline & $\begin{array}{l}\text { Escharoporidae } \\
\text { (?Stictoporellidae) }\end{array}$ & Oanduella & Ordovician & $\begin{array}{l}\text { Karklins (1983); Goryunova } \\
\text { and Lavrentjeva (1993) }\end{array}$ \\
\hline & $\begin{array}{l}\text { Escahroporidae } \\
\text { (?Ptilodictyidae) }\end{array}$ & Proavella & Ordovician & $\begin{array}{l}\text { Karklins (1983); Goryunova } \\
\text { and Lavrentjeva (1993) }\end{array}$ \\
\hline & Intraporidae & Coscinella & Devonian & Karklins (1983) \\
\hline & $\begin{array}{l}\text { Rhinidictyidae } \\
\text { (?Ptilodictyidae) }\end{array}$ & Sibiredictya & Ordovician & $\begin{array}{l}\text { Karklins (1983); Goryunova } \\
\text { and Lavrentjeva (1993) }\end{array}$ \\
\hline Cyclostomata & ?Multisparsidae & Rorypora & Jurassic & This paper \\
\hline \multirow[t]{4}{*}{ Cheilostomata } & Onychocellidae & Nudicella & Paleocene-Miocene & Schmidt and Bone (2004) \\
\hline & Aspidostomatidae & Aspidostoma livida & Recent & Hayward and Cook (1983) \\
\hline & Adeonidae & Adeona & Recent & Kirchenpauer (1880) \\
\hline & Adeonidae & $\begin{array}{l}\text { Dimorphocella } \\
\text { moderna }\end{array}$ & Recent & Hayward and Cook (1983) \\
\hline
\end{tabular}


Fig. 3 Fragments of cribrate colonies belonging to different bryozoan higher taxa showing the striking convergence in colony-form. All photographs are at the same scale. a Adeona albida Kirchenpauer, 1880 (Cheilostomata, Adeonidae), Recent, Australia, NHM 83.10.15.2. b Nudicella cribriforma Schmidt and Bone, 2004 (Cheilostomata, Onychocellidae), Eocene (Tortachilla Fm), Maslin Beach, South Australia, NHM BZ5835. c Aspidostoma livida Hayward \& Cook, 1983 (Cheilostomata, Aspidostomatidae), Recent, South Africa, NHM 1983.11.5.3. d Dimorphocella moderna Hayward \& Cook, 1983 (Cheilostomata, Adeonidae), Recent, South Africa, NHM 1983.11.5.24. e Clathropora intertexta Nicholson, 1874 (Cryptostomata, Ptilodictyidae), Devonian (Hamilton Group), Arkona, Ontario, Canada, NHM PD2103. f Stictoporellina sp. (Cryptostomata,

Stictoporellidae), Ordovician (Wesinberg Limestone),

Pechurki Limestone Quarry, Leningrad Oblast, Russia, NHM BZ5836. g Coscinotrypa cribriformis (Prout, 1859) (Cystoporata, Hexagonellidae), Devonian (Hamilton Group), Falls of the Ohio, Indiana, USA, NHM D5761

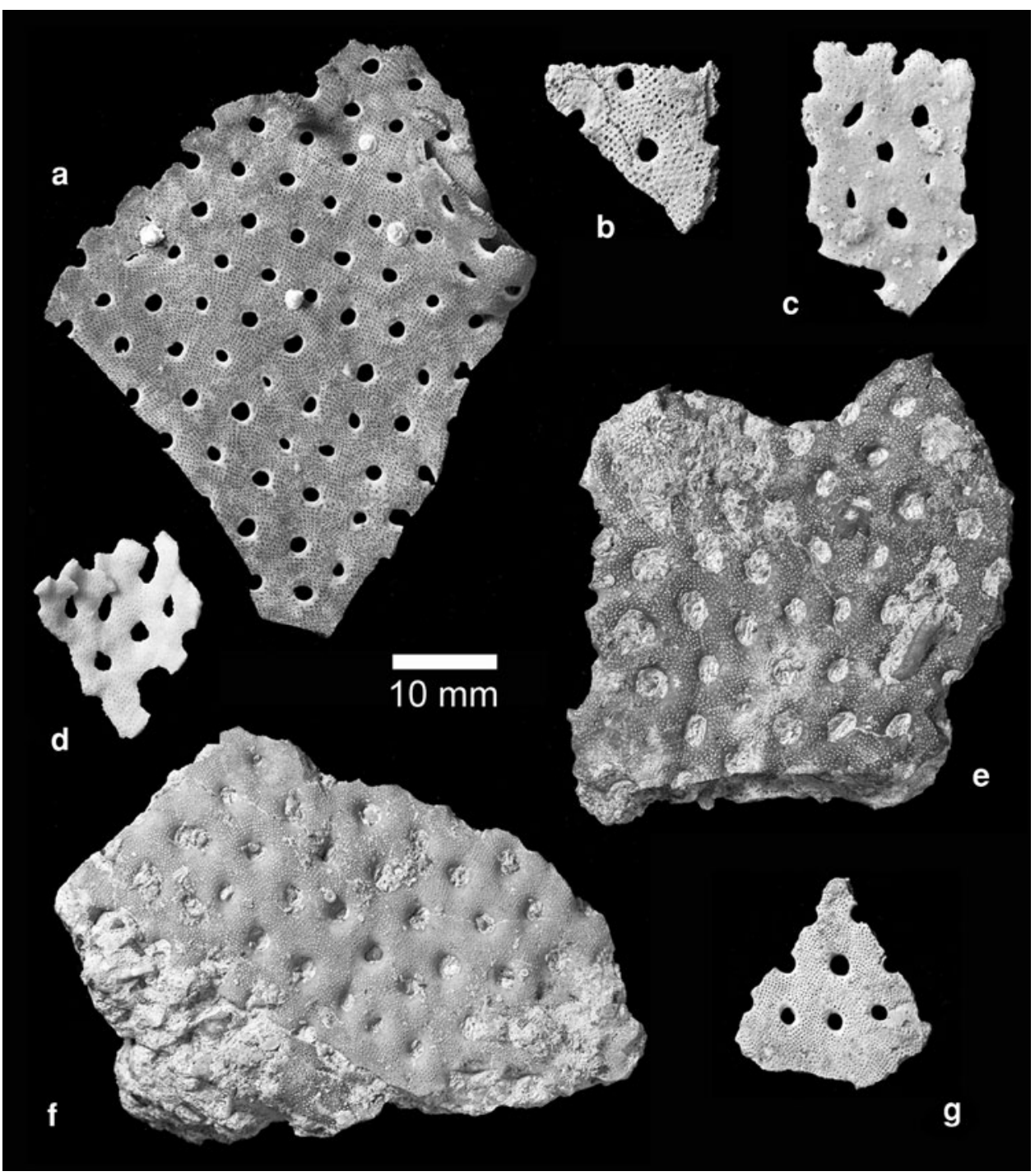

The scattered taxonomic distribution of bryozoan genera with cribrate colonies leaves no doubt that the colony-form has evolved convergently on numerous occasions (note that some of the putative cribrate bryozoans listed by Schmidt and Bone (2004, p. 200) actually have fenestrate colonyforms, e.g. Smittipora fenestrata d'Hondt \& Gordon). Even within bryozoan orders, it is apparent that cribrate colonies have evolved more than once. The clearest case is in the Cheilostomata where cribrates are found in three distantly related families (Onychocellidae, Aspidostomatidae and Adeonidae). Cribrate colonies are strikingly similar (Fig. 3) among different bryozoan groups and provide one of the best examples of evolutionary convergence in a phylum where this phenomenon is pervasive. In contrast to the similarities in colony-form between these cribrate taxa, the skeletal morphology of the zooids differs substantially (Fig. 4), reflecting the varied higher taxonomic affinities of the species.
The size of the lacunae in cribrate bryozoans varies both within and between colonies (Supplementary Material). The area of measured lacunae ranged from 0.42 to $31.47 \mathrm{~mm}^{2}$

Fig. 4 Scanning electron micrographs showing lacunae and zooids in cribrate colonies belonging to different higher taxa of bryozoans. a Stictoporellina sp. (Cryptostomata, Stictoporellidae), Ordovician (Wesinberg Limestone), Pechurki Limestone Quarry, Leningrad Oblast, Russia, NHM BZ5837; note subcircular autozooidal apertures. b, c Coscinotrypa cribriformis (Prout, 1859) (Cystoporata, Hexagonellidae), Devonian (Hamilton Group), Falls of the Ohio, Indiana, USA, NHM D5761; silicified colony with stereom surrounding the lacuna (b), and forming a macula (c, right). d Aspidostoma livida Hayward \& Cook, 1983 (Cheilostomata, Aspidostomatidae), Recent, South Africa, NHM 1983.11.5.3; note kenozooids lining lacuna. e Dimorphocella moderna Hayward \& Cook, 1983 (Cheilostomata, Adeonidae), Recent, South Africa, NHM 1983.11.5.24; autozooids have a conspicuous orificial sinus and most are associated with an elongate avicularium. f Adeona wilsoni (MacGillivray, 1881), Recent, Port Western, Australia, NHM 99.7.1.58; kenozooids are developed around the lacuna. Scale bars $500 \mu \mathrm{m}$ 


(average $3.94 \mathrm{~mm}^{2}$ ), and the proportion of the colony surface occupied by lacunae from 3.3 to $24.1 \%$ (average $11.8 \%$ ). Of the two orders with the greatest number of cribrate species, Cenozoic-Recent cheilostomes tend to have a smaller proportion of the colony surface taken up by lacunae than do Palaeozoic cryptostomes (Fig. 5).

In terms of geological occurrence (Table 1), cribrate colonies are most common in the Palaeozoic (12 genera), especially the Ordovician early in the evolutionary history of the phylum. By contrast, only one Mesozoic (Rorypora) and four Cenozoic-Recent cribrate genera are known to possess cribrate colonies.

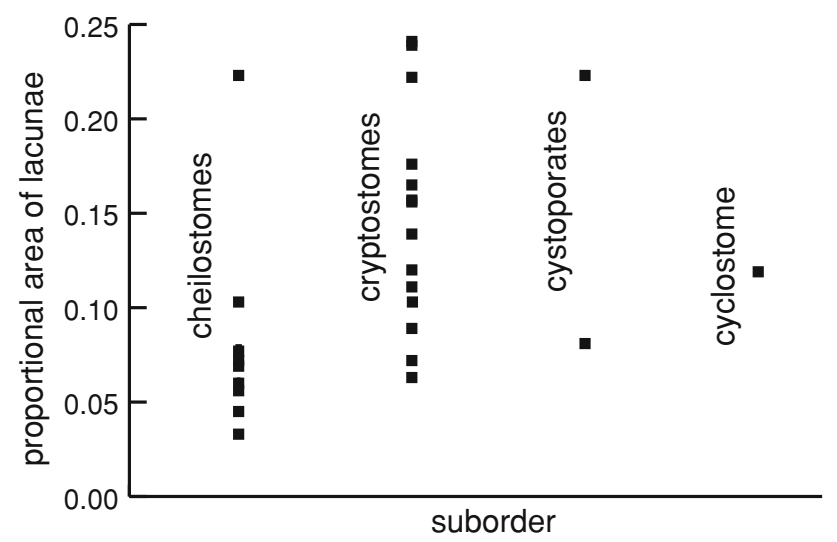

Fig. 5 Comparison between the proportion of lacunae area to total surface area in species of cribrate bryozoans belonging to the orders Cheilostomata, Cryptostomata, Cystoporata and Cyclostomata. See Supplementary Material for source data
Functional morphology of cribrate colonies

Cribrate colonies can be interpreted functionally in terms of the multizooidal current systems that are likely to have been established for feeding purposes. Bryozoans are active suspension feeders, each autozooid creating a current that enters the open end of the lophophore and passes radially outwards between the tentacles (see McKinney 1990). At the level of the colony, the interacting feeding currents of individual autozooids are integrated such that some regions of the colony surface function as areas of inhalant water flow and others as exhalent chimneys. Mapping the distribution of apertures of autozooids, and hence lophophores, allows the pattern of multizooidal currents to be inferred in fossil colonies (see Taylor 1999 and references therein), as well as in Recent colonies which have not been observed feeding, including the extant cheilostome species possessing cribrate colonies.

Apertures of autozooids in cribrate colonies cover the surfaces of the bifoliate branches more or less evenly on both sides of the colony. However, lophophores are obviously lacking over the lacunae. Therefore, frond surfaces should form regions of inhalant flow and filtered water should be passed towards the lacunae for expulsion. Exhalent currents cannot, however, flow through the lacunae because of the presence of autozooids on both sides of the colony generating converging inhalant currents. Instead, exhalent currents must be channeled upwards away from the holes to form diverging exhalent chimneys on opposite sides of the colony (Fig. 6a).
Fig. 6 Colonial feeding currents in bryozoans with cribrate (a) and fenestrate (b) colony-forms. Branches shown in cross section along with autozooidal lophophores. Small arrows signify prevailing current directions created by individual autozooids, large arrows the colonial flow pattern. Whereas water flows through the gaps (fenestrules) between the branches of fenestrate colonies, in cribrate colonies the gaps (lacunae) between branches are inferred to be sites of divergent exhalent chimneys

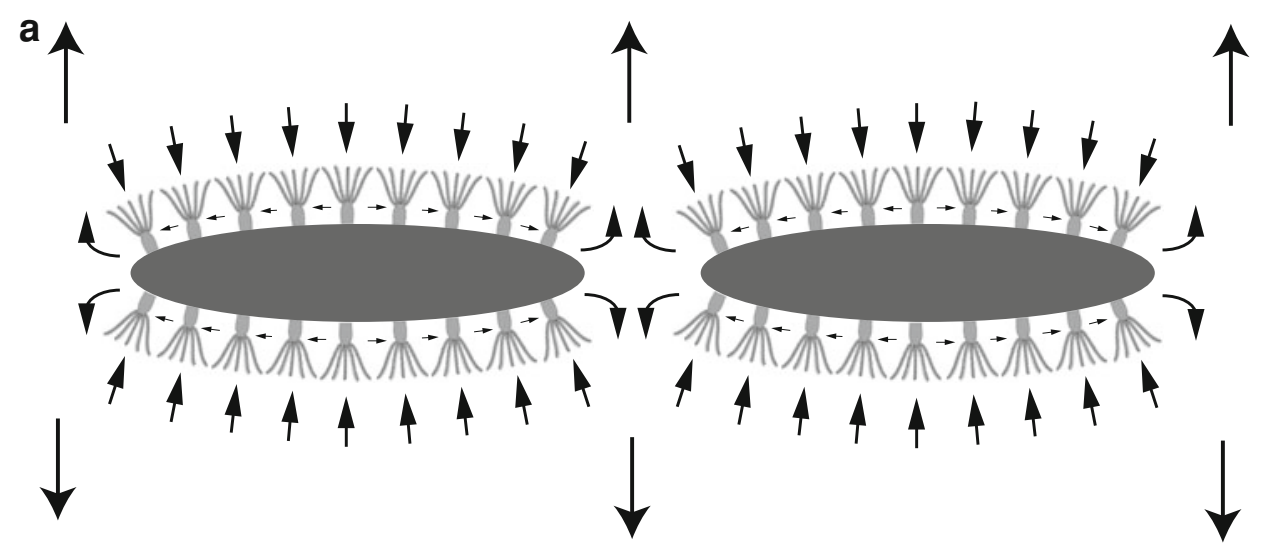

b

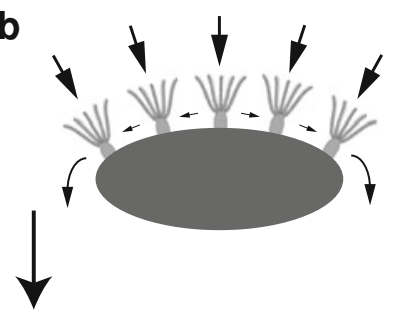

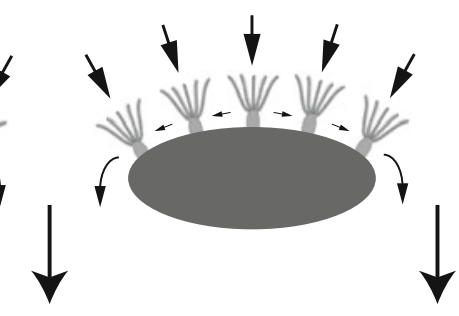


It should be noted that this multizooidal current pattern is inferred without reference to ambient flow. Schmidt and Bone (2004) remarked that most cribrate species seem to occur in higher-energy environments, so some interference between bryozoan-generated and ambient currents is likely to occur. Should ambient flow be particularly strong, water could be forced through the lacunae in the direction of prevailing ambient flow. However, any functional asymmetry between the two sides of the colony is not obviously reflected in the skeletal morphologies of the cribrate species studied here.

The current system inferred for cribrate colonies contrasts with that seen in superficially similar bryozoans that have fenestrate colonies. In fenestrates the presence of current-generating autozooids only on one side of the colony allows the lacunae (fenestrules) to act as conduits for the unidirectional flow of water (e.g. Cook 1977; McKinney, 1990; Fig. 6b), from the frontal side of the colony bearing autozooids towards the obverse side of the colony devoid of autozooids.

The area over which excurrents are vented in cribrate colonies can be somewhat greater than the size of the lacunae because in many species a rim of non-feeding zooids (Fig. 4a, d, f) or a band of stereom (Fig. 4b) surrounds the lacunae. This represents another difference with fenestrate colonies where autozooids typically occur around the fenestrules and lophophores may actually project into the fenestrules themselves (McKinney 1990).

Despite their superficial resemblance to the fenestrules of fenestrate colonies, the lacunae of cribrate colonies are functional equivalents of maculae (including monticules) that constitute sites of exhalent chimneys in many bryozoans. Although maculae are normally lacking in cribrate bryozoans, a fragment of the cribrate cystoporate Coscinotrypa (Fig. 4c) does possess at least one macula, suggesting that chimneys in this colony were located in two alternative positions, over the maculae and over the lacunae.

\section{Conclusions}

The description of the new cyclostome genus Rorypora adds to the diversity of bryozoan taxa with cribrate colonies in which flattened, bifoliate branches divide and anastomose at regular intervals to enclose subcircular lacunae. Rorypora appears to be the only Mesozoic bryozoan with a cribrate colony, as well as the only cyclostome known to have this colony-form.

The distribution of apertures of autozooids can be used to infer the patterning of lophophores across the colony surface of cribrate colonies and hence the multizooidal feeding currents established by the colony for efficient filtering of plankton. In contrast to the commoner fenestrate colony-form in which the fenestrules in the colony function as conduits for a unidirectional flow of water from one side of the colony to the other, cribrate colonies cannot vent water through the equivalent lacunae because of the presence of feeding zooids on both sides of the colony. Instead, the lacunae of cribrate colonies are inferred to be sites of exhalent chimneys venting filtered water in opposite directions from either side of the colony.

Stages in the evolution of cribrate colonies can be envisaged as: (1) progressive restriction of a bushy threedimensional colony with strap-like bifoliate fronds to a two-dimensional planar form; (2) increasing frequency of anastomoses between fronds growing in the same plane; and (3) regularization of the pattern of frond bifurcation and anastomosis to give a planar colony with evenly spaced lacunae. This sequence parallels that proposed for the evolution of the fenestrate colony-form (Taylor 1987); however, in fenestrates the starting point was from a colony with radially symmetrical branches rather than bifoliate fronds and an additional stage involved the loss of feeding zooids from one side of the branches.

Acknowledgments Dr Heinz Furrer (Paläontologisches Institut und Museum, Universität Zurich) is thanked for allowing me access to the collections under his care and arranging a loan. I am very grateful to work experience student Robyn Pointer (Imperial College, London) for compiling data on cribrate bryozoans, and to two anonymous reviewers for helpful comments.

\section{References}

Bassler, R. S. (1935). Bryozoa. Fossilium Catalogus, 67, 1-229.

Busk, G. (1852). An account of the Polyzoa and Sertularian Zoophytes collected in the voyage of the Rattlesnake on the coast of Australia and the Louisiade Archipelago. In J. MacGillivray (Ed.), Narrative of the Voyage of H.M.S. Rattlesnake, commanded by the late Captain Owen Stanley, during the years 1846-1850, 1 (pp. 343-402). London: Boone.

Canu, F. (1918). Les ovicelles des Bryozoaires cyclostomes. Étude sur quelques familles nouvelles et anciennes. Bulletin de la Societé Géologique de France, 16(4), 324-335.

Cook, P. L. (1977). Colony-wide water currents in living Bryozoa. Cahiers de Biologie Marine, 18, 31-47.

de Tribolet, M. (1872). Notice géologique sur le Mont Chatelu. Essai de synchronisme entre les terrains du Jura blac argovienet ceux de la Suisse occidentale. Bulletin de la Société des Sciences Naturelles de Neuchatel, 9, 267-296.

de Tribolet, M. (1873). Recherches géologiques \& paléontologiques dans le Jura supérieur neuchâtelois. Zurich: Zurcher et Furrer.

Goryunova, R. V. (1994). The taxonomic rank and phylogeny of the timanodictyoid bryozoans. Paleontological Journal, 28(2), 51-70.

Goryunova, R. V., \& Lavrentjeva, V. D. (1993). [Morphology and system of the cryptostome bryozoans]. Trudy Paleontologischeskogo Instituta Akademiya Nauk SSSR, 257, 1-150. (in Russian).

Haime, J. (1854). Description des Bryozoaires fossiles de la formation Jurassique. Mémoires de la Société Géologique de France, 5, $157-218$. 
Harmelin, J.-G. (1976). Relations entre la forme zoariale et l'habitat chez les Bryozoaires Cyclostomes. Consequences taxonomiques. Documents des Laboratoires de Géologie de la Faculté des Sciences de Lyon, HS 3, 369-384.

Karklins, O. L. (1983). Systematic descriptions for the suborder Ptilodictyina. In R. S. Boardman, et al. (Eds.), Treatise on Invertebrate Paleontology. Part G. Bryozoa. Revised (pp. 453-488). Boulder and Lawrence: Geological Society of America and University of Kansas Press.

Kirchenpauer, G. H. (1880). Über die Bryozoen-Gattung Adeona. Abhandlungen aus dem Gebiete der Naturwissenschaften, Herausgegeben von dem naturwissenschaftlichen Verein in Hamburg, 7, 1-24.

Lamouroux, J. V. F. (1812). Extrait d'un mémoire sur la classification des Polypiers coralligènes non entièrement pierreux. Nouveau Bulletin Scientifique de la Société Philosophique, 3, 181-188.

Lamouroux, J. V. F. (1821). Exposition méthodique des genres de l'ordre des polypiers, avec leur description et celles des principales espèces figurées dans 84 planches; les 63 premières apartenant à l'Histoire naturelle des Zoophytes d'Ellis et Solander. Paris: V. Agasse.

McKinney, F. K. (1990). Feeding and associated colonial morphology in marine bryozoans. Reviews in Aquatic Sciences, 2, 255-280.

Milne Edwards, H. (1838). Mémoire sur les crisies, les hornères et plusiers autres polypes vivants ou fossiles dont l'organisation est analogue à celle des tubulipores. Annales des Sciences Naturelles Zoologie, 9(2), 193-238.

Schmidt, R., \& Bone, Y. (2004). Australian Caenozoic Bryozoa, 1: Nudicella gen. nov. (Onychocellidae, Cheilostomata): taxonomy, palaeoenvironments and biogeography. Alcheringa, 28, 185-203.

Schopf, T. J. M. (1969). Paleoecology of ectoprocts (bryozoans). Journal of Paleontology, 43, 234-244.
Spjeldnaes, N. (1996). Bryozoan colonies as indicators of bottom conditions in the Lower Ordovician. In D. P. Gordon, A. M. Smith, \& J. A. Grant-Mackie (Eds.), Bryozoans in Space and Time (pp. 315-319). Wellington: NIWA.

Taylor, P. D. (1987). Fenestrate colony-form in a new melicerititid bryozoan from the $\mathrm{U}$ Cretaceous of Germany. Mesozoic Research, 1, 71-77.

Taylor, P. D. (1999). Bryozoa. In E. Savazzi (Ed.), Functional morphology of the invertebrate skeleton (pp. 623-646). Chichester: Wiley.

Taylor, P. D. (2009). Bryozoans from the Middle Jurassic of Balin, Poland: a revision of material described by A.E. Reuss (1867). Annalen des Naturhistorischen Museums in Wien, Serie A, 110, 17-54.

Taylor, P. D., \& Ernst, A. (2008). Bryozoans in transition: the depauperate and patchy Jurassic biota. Palaeogeography, Palaeoclimatology, Palaeoecology, 263, 9-23.

Utgaard, J. (1983). Systematic descriptions for the Order Cystoporata. In R. S. Boardman, et al. (Eds.), Treatise on Invertebrate Paleontology. Part G. Bryozoa. Revised (pp. 358-439). Boulder and Lawrence: Geological Society of America and University of Kansas Press.

Waeschenbach, A., Cox, C. C., Littlewood, D. T. J., Porter, J. S., \& Taylor, P. D. (2009). First molecular estimate of cyclostome bryozoan phylogeny confirms extensive homoplasy among skeletal characters used in traditional taxonomy. Molecular Phylogenetics and Evolution, 52, 241-251.

Walter, B. (1970). Les Bryozoaires Jurassiques en France. Documents des Laboratoires de Géologie de la Faculté des Sciences de Lyon, 35 [for 1969], 1-328. 